\title{
The Impact of Using Google Concordancer and Creating Online Crosswords on EFL Learners' Self-Regulation in Vocabulary Learning: A Discovery Learning Approach
}

\author{
Mahshad Tasnimi \\ Assistant Professor of TEFL at Islamic Azad University \\ North-Tehran Branch, Tehran, Iran \\ mtasnimi@yahoo.com \\ Mahya Afzalinejad Ravari \\ Department of English, Islamic Azad University \\ North-Tehran Branch, Tehran, Iran \\ Mahya.afzali@gmail.com
}

\begin{abstract}
This study aimed to explore the effect of using Google concordancer and creating online crosswords on EFL learners' self-regulation in vocabulary learning. This study was conducted on two experimental groups and one control group. The first experimental group received the intervention through using Google as a concordancer in vocabulary learning and the second experimental group learned vocabulary items through creating online crosswords, while in control group, the traditional procedure of vocabulary teaching was taken into consideration. The participants completed a questionnaire on self-regulation in vocabulary learning twice as pretest and posttest during the study. This questionnaire was developed by Tseng, Dornyei, and Schmitt in (2006) on self-regulation in L2 vocabulary learning (Appendix A). A one-way ANOVA was employed to examine the changes in participants' self- regulation over the course of the study. Finally, some statistical analysis was conducted. The results of statistical analysis indicated that the group who received the intervention through creating online crosswords had a significantly better performance in terms of self-regulation. The findings of the current study provided empirical evidence suggesting that through learning by discovery approach specially creating online crosswords, it might be possible to enhance self-regulation which is considered to be an important factor in the learning of English.
\end{abstract}

Keywords: Self-regulation, Discovery Learning, Google Concordancer, Creating Online Crosswords.

\section{INTRODUCTION}

The importance of vocabulary learning has been addressed by several writers (Alqahtani, 2015; Ebrahimi, Azhideh, and Aslanabadi, 2015), and it has drawn a great deal of attention among EFL learning setting. Despite the vital role of vocabulary learning, little attention has been paid to its instruction and its effective factors. According to Wilkins (1972) "....while without grammar very little can be conveyed, without vocabulary nothing can be conveyed" (p. 111). This means that, EFL learners need to develop their vocabulary knowledge in order to communicate appropriately in L2 situations. L2 learners need to develop a sufficient level of vocabulary knowledge to accomplish their daily conversations and to read authentic materials, so that possessing a good level of self-regulation is vital in vocabulary learning improvement (Tseng, Dörnyei, and Schmitt, 2006). In a study conducted by Mizumoto (2013), exploring a method with a focus on self-regulation and its effects on self-efficacy in vocabulary learning, Mizumoto concluded that using a self-regulated learning approach enhances self-efficacy which contributes to vocabulary learning. Moreover, previous studies confirmed the effectiveness of discovery and computer-based approaches in vocabulary learning (Ebrahimi, Azhideh, and Aslanabadi, 2015; Constantinescu, 2007).

The importance of self-regulated learning has been confirmed in Maftoon and Tasnimi's (2014) study. They focused on the use of self-regulation as a strategy to enhance reading comprehension in Iranian learners and came to the conclusion that self-regulated tasks in textbooks encourage students to participate actively in their learning process and can contribute to both learning and motivation of the learners. 
Balım (2009) elaborated on the effects of discovery learning on students' perceptions of inquiry learning skills, academic achievements, and retention of knowledge and came to the conclusion that discovery learning method enhances students' success and inquiry learning skills.

One aspect of discovery learning can be shown through the use of Google concordancer and online crosswords in vocabulary learning. According to Saif Modhish and Talib Al-kadi (2016), the Internet is making the classes more learner-centered and is trying to improve self-directed teaching and learning. Moreover, with the help of search engines and social media networks, teachers are moving toward combining the internet with their teaching classes.

To sum it up, the effect of discovery learning on self-regulation in vocabulary learning had not been determined yet, so the purpose of this study was to evaluate the effect of using Google as a concordancer and creating online crosswords as an aspect of discovery learning on learners' selfregulation in vocabulary learning.

\section{Materials AND MethodS}

This was an experimental study of $60 \mathrm{EFL}$ students at intermediate level of language proficiency studying in Tehran in 2015. They were randomly assigned into two experimental groups and one control group. Their gender was not taken into consideration and their first language was Persian. First, PET exam was administered to ensure the homogeneity of the participants in terms of language proficiency. Then, as their pretest, all three groups were asked to answer the self-regulation questionnaire which was designed by Tseng, Dörnyei, and Schmitt in (2006). Afterwards, both experimental groups had a 10-session intervention based on discovery learning approach. In experimental groups, vocabulary items were taught through learner's contribution to find the meaning themselves and creating their own conceptual structure and conclusion, not by direct instruction of the teacher and explicit learning in which the instructor clearly outlines what the learning goals are for the students. Experimental group I was provided with the Internet access by which they could use Google as a concordancer for finding the meanings of the new words. Every session, they googled the words and saw the results. They found out about the actual uses of the words in real life situation and their preceding and following word options.

Experimental group II was exposed to discovery learning from a different view. They learned new vocabulary items through creating online crosswords. This group had the Internet access as well and they built their own crosswords by the new words every session. While they were working on their crosswords, they had to find the meaning of the words on their dictionaries, provided on their phones or printed ones. After building their puzzles and checking the correction of the crosswords by the teacher, they exchanged their crosswords with another pair and they solved the crossword puzzles.

The control group learned the new words through conventional procedure of vocabulary teaching by direct instruction of teacher in 10 sessions of intervention. The overall framework of conventional vocabulary procedure was providing the learners with a synonym, example, or definition of the new word, checking their understandings, and asking for a choral repetition. All groups were taught by the same teacher and they were exposed to the same material which was Oxford Word Skills.

After the intervention, they filled in the questionnaire for the second time and their answers were analyzed based on the changes on the level of their self-regulation. Statistical analysis was carried out using Statistical Package for Social Sciences (SPSS) software. In order to answer the research question formulated for this study, descriptive statistics such as means and standard deviation were computed. Inferential statistics of one-way ANOVA was used in this study three times. First, to assure the homogeneity of the participants; second, to make sure that the participants of the three groups were not significantly different in terms of their self-regulation prior to the main study; and third, to explore the differences between control and experimental groups in terms of self-regulation after the intervention.

\section{RESULTS AND DISCUSSION}

We compared the changes in the level of self-regulation in pretest and posttest of the groups. The result revealed a statistically significant difference between the group means on the posttest of selfregulation analyzed by one-way $\operatorname{ANOVA}\left(\mathrm{F}(2,57)=7.39, \mathrm{p}=.001, \omega^{2}=.176\right.$ representing a large effect size). The group which received the intervention through creating online crosswords had a significantly better performance in terms of self-regulation. 
The Impact of Using Google Concordancer and Creating Online Crosswords on EFL Learners' SelfRegulation in Vocabulary Learning: A Discovery Learning Approach

This result was followed by the group that used Google concordancer as a way of vocabulary learning, and lastly by the control group which was exposed to the conventional procedure of vocabulary teaching. The experimental group II obtained higher scores in the posttest in comparison to the pretest, which reflected the change in the level of their self-regulation during the course and made posttest scores statistically significant. Thus, the crossword puzzle group with the mean of 111.90 in the posttest outperformed the Google concordancer group with the mean of 106.75 and the control group, whose mean was 90.50 . The results are illustrated in table below.

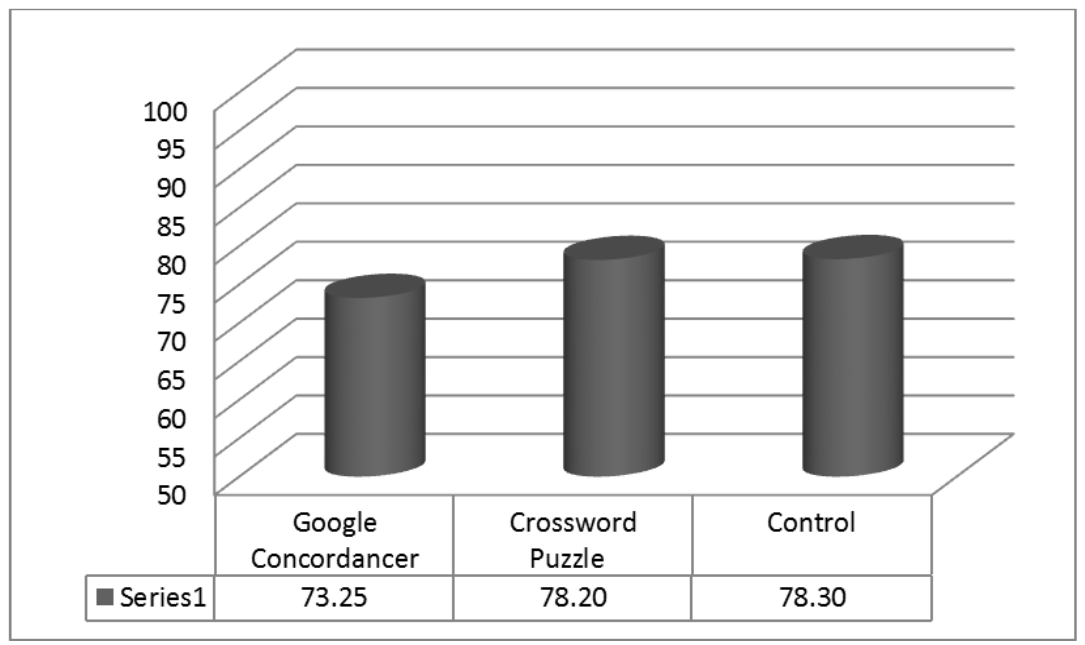

Figure1. Mean scores; PET by group

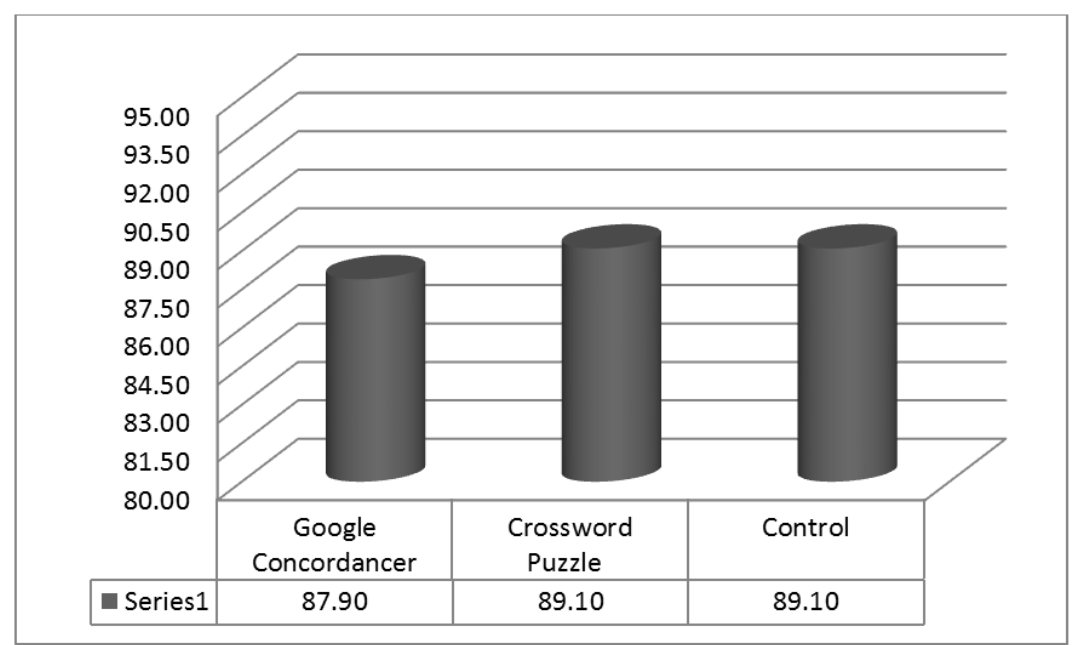

Figure2. Mean scores; pretest of self-regulation by groups

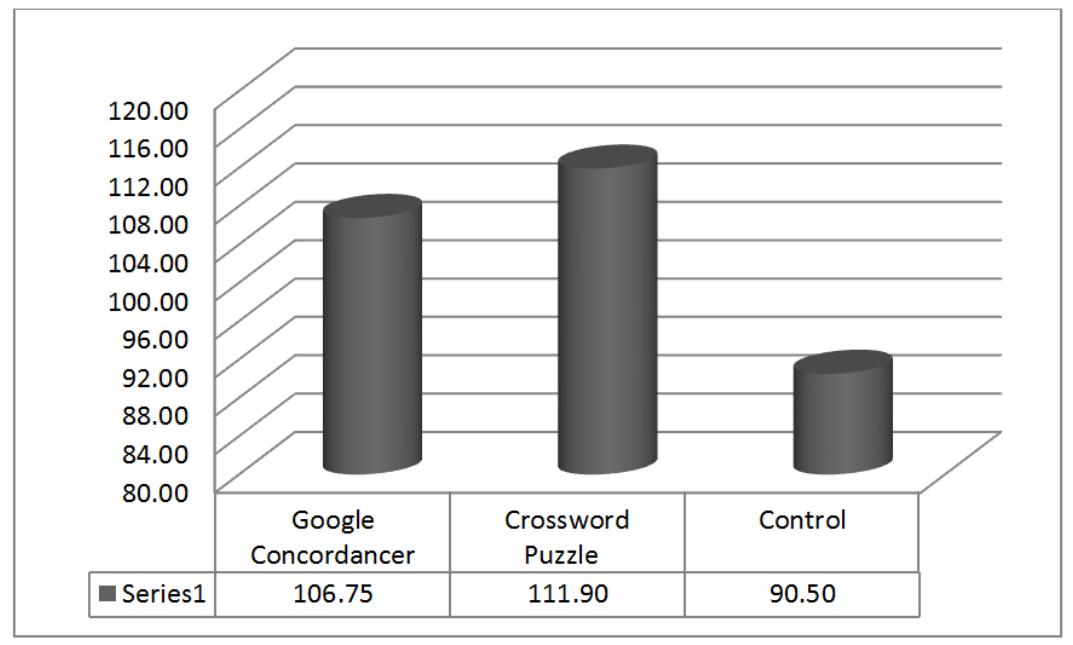

Figure3. Mean scores; posttest of self-regulation by groups 
Mahshad Tasnimi \& Mahya Afzalinejad Ravari

Table4.1. Descriptive Statistics; Testing Normality Assumption

\begin{tabular}{|c|c|c|c|c|c|c|c|c|}
\hline \multirow{2}{*}{\multicolumn{2}{|c|}{ Group }} & $\mathrm{N}$ & \multicolumn{3}{|c|}{ Skewness } & \multicolumn{3}{|c|}{ Kurtosis } \\
\hline & & Statistic & Statistic & Std. Error & Ratio & Statistic & Std. Error & Ratio \\
\hline \multirow{3}{*}{$\begin{array}{l}\text { Google } \\
\text { Concordancer }\end{array}$} & PET & 20 & -.145 & .512 & -0.30 & -.415 & .992 & -0.41 \\
\hline & Pretest & 20 & .133 & .512 & 0.26 & -.450 & .992 & -0.45 \\
\hline & Posttest & 20 & -.011 & .512 & -0.02 & -.543 & .992 & -0.55 \\
\hline \multirow{3}{*}{$\begin{array}{l}\text { Crossword } \\
\text { Puzzle }\end{array}$} & PET & 20 & .712 & .512 & 1.39 & .035 & .992 & 0.03 \\
\hline & Pretest & 20 & .535 & .512 & 1.04 & .148 & .992 & 0.15 \\
\hline & Posttest & 20 & .852 & .512 & 1.66 & .884 & .992 & 0.89 \\
\hline \multirow[t]{3}{*}{ Control } & PET & 20 & -.451 & .512 & -0.88 & -.040 & .992 & -0.04 \\
\hline & Pretest & 20 & -.396 & .512 & -0.77 & -.956 & .992 & -0.96 \\
\hline & Posttest & 20 & -.357 & .512 & -0.70 & -.778 & .992 & -0.78 \\
\hline
\end{tabular}

Table4.2. Test of Homogeneity of Variances; Pretest of Self-Regulation

\begin{tabular}{|l|l|l|l|}
\hline Levene Statistic & df1 & df2 & Sig. \\
\hline .883 & 2 & 57 & .419 \\
\hline
\end{tabular}

Table4.3. Descriptive Statistics; PET General Language Proficiency Test by Groups

\begin{tabular}{|l|l|l|l|l|l|l|l|l|}
\hline & N & Mean & \multirow{2}{*}{$\begin{array}{l}\text { Std. } \\
\text { Deviation }\end{array}$} & \multirow{2}{*}{$\begin{array}{l}\text { Std. } \\
\text { Error }\end{array}$} & & & & \multicolumn{2}{l}{$\begin{array}{l}\text { 95\% Confidence } \\
\text { Interval for Mean }\end{array}$} & \multirow{2}{*}{ Min } & \multirow{2}{*}{ Max } \\
\cline { 6 - 9 } & & & & & Lower Bound & Upper Bound & & \\
\hline Google Concordancer & 20 & 73.25 & 11.639 & 2.603 & 67.80 & 78.70 & 52 & 96 \\
\hline Crossword Puzzle & 20 & 78.20 & 8.532 & 1.908 & 74.21 & 82.19 & 66 & 97 \\
\hline Control & 20 & 78.30 & 10.844 & 2.425 & 73.22 & 83.38 & 57 & 95 \\
\hline Total & 60 & 76.58 & 10.516 & 1.358 & 73.87 & 79.30 & 52 & 97 \\
\hline
\end{tabular}

Table4.4. One-Way ANOVA; PET General Language Proficiency Test by Groups

\begin{tabular}{|l|l|l|l|l|l|}
\hline & Sum of Squares & df & Mean Square & F & Sig. \\
\hline Between Groups & 333.433 & 2 & 166.717 & 1.535 & .224 \\
\hline Within Groups & 6191.150 & 57 & 108.617 & & \\
\hline Total & 6524.583 & 59 & & & \\
\hline
\end{tabular}

Table4.5. Test of Homogeneity of Variances; Pretest of Self-Regulation

\begin{tabular}{|l|l|l|l|}
\hline Levene Statistic & df1 & df2 & Sig. \\
\hline .618 & 2 & 57 & .543 \\
\hline
\end{tabular}

Table4.6. Descriptive Statistics; Pretest of Self-Regulation by Groups

\begin{tabular}{|c|c|c|c|c|c|c|c|c|}
\hline & \multirow[t]{2}{*}{$\mathrm{N}$} & \multirow[t]{2}{*}{ Mean } & \multirow[t]{2}{*}{$\begin{array}{l}\text { Std. } \\
\text { Deviation }\end{array}$} & \multirow[t]{2}{*}{$\begin{array}{l}\text { Std. } \\
\text { Error }\end{array}$} & \multicolumn{2}{|c|}{$\begin{array}{l}95 \% \text { Confidence } \\
\text { Interval for Mean }\end{array}$} & \multirow[t]{2}{*}{ Min } & \multirow[t]{2}{*}{ Max } \\
\hline & & & & & Lower Bound & Upper Bound & & \\
\hline Google Concordancer & 20 & 87.90 & 17.645 & 3.946 & 79.64 & 96.16 & 55 & 120 \\
\hline Crossword Puzzle & 20 & 89.10 & 21.171 & 4.734 & 79.19 & 99.01 & 59 & 134 \\
\hline Control & 20 & 89.10 & 22.247 & 4.975 & 78.69 & 99.51 & 51 & 123 \\
\hline Total & 60 & 88.70 & 20.108 & 2.596 & 83.51 & 93.89 & 51 & 134 \\
\hline
\end{tabular}

Table4.7. One-Way ANOVA; Pretest of Self-Regulation by Groups

\begin{tabular}{|l|l|l|l|}
\hline & Sum of Squares & df & Mean Square \\
\hline Between Groups & 19.200 & 2 & 9.600 \\
\hline Within Groups & 23835.400 & 57 & 418.165 \\
\hline Total & 23854.600 & 59 & \\
\hline
\end{tabular}

Table4.8. Test of Homogeneity of Variances; Posttest of Self-Regulation

\begin{tabular}{|l|l|l|l|}
\hline Levene Statistic & df1 & df2 & Sig. \\
\hline 3.112 & 2 & 57 & .052 \\
\hline
\end{tabular}


The Impact of Using Google Concordancer and Creating Online Crosswords on EFL Learners' SelfRegulation in Vocabulary Learning: A Discovery Learning Approach

Table4.9. Descriptive Statistics; Posttest of Self-Regulation by Groups

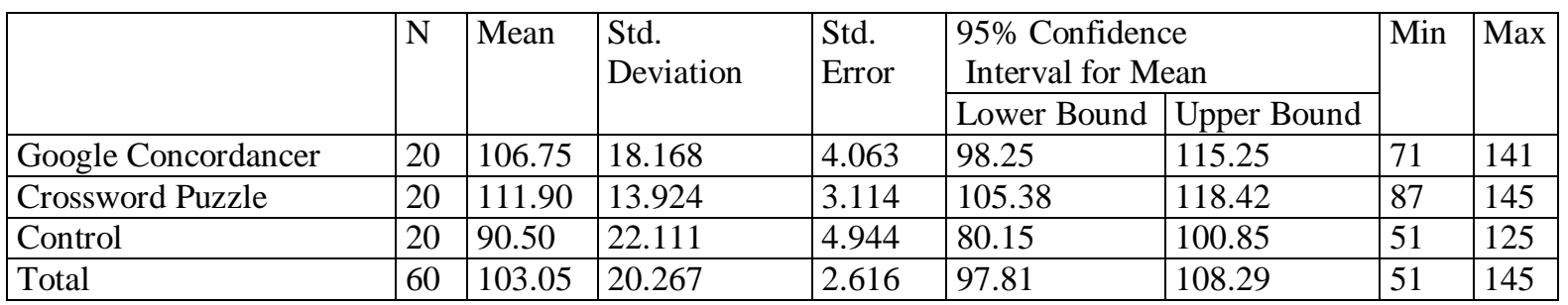

Table4.10. One-Way ANOVA; Posttest of Self-Regulation by Groups

\begin{tabular}{|l|l|l|l|l|l|}
\hline & Sum of Squares & df & Mean Square & F & Sig. \\
\hline Between Groups & 4990.300 & 2 & 2495.150 & 7.390 & .001 \\
\hline Within Groups & 19244.550 & 57 & 337.624 & & \\
\hline Total & 24234.850 & 59 & & & \\
\hline
\end{tabular}

Table4.11. Multiple Comparisons; Posttest of Self-Regulation by Groups

\begin{tabular}{|c|c|c|c|c|c|c|}
\hline \multirow[t]{2}{*}{ (I) Group } & \multirow[t]{2}{*}{ (J) Group } & \multirow{2}{*}{$\begin{array}{l}\text { Mean } \\
\text { Difference } \\
(\mathrm{I}-\mathrm{J})\end{array}$} & \multirow[t]{2}{*}{ Std. Error } & \multirow[t]{2}{*}{ Sig. } & \multicolumn{2}{|c|}{ 95\% Confidence Interval } \\
\hline & & & & & $\begin{array}{l}\text { Lower } \\
\text { Bound }\end{array}$ & $\begin{array}{l}\text { Upper } \\
\text { Bound }\end{array}$ \\
\hline $\begin{array}{l}\text { Google } \\
\text { concordancer }\end{array}$ & Control & $16.250^{*}$ & 5.811 & .026 & 1.65 & 30.85 \\
\hline \multirow[t]{2}{*}{ crossword puzzle } & $\begin{array}{l}\text { Google } \\
\text { concordancer }\end{array}$ & 5.150 & 5.811 & .677 & -9.45 & 19.75 \\
\hline & Control & $21.400^{*}$ & 5.811 & .002 & 6.80 & 36.00 \\
\hline
\end{tabular}

\section{CONCLUSION}

The purpose of this study was to examine the effect of Google concordancer and online crosswords on EFL learners' self-regulation in vocabulary learning. According to the result of the study, creating online crosswords was significantly more effective than using Google concordancer and conventional way of vocabulary teaching in terms of self-regulation. In other words, the learners who received the intervention through creating online crosswords had a better performance in their posttest in comparison to their pretest.

There are some possible explanations for this betterment. One possible factor is that discovery learning is the main component of creating online crosswords and learning by discovery is an important factor in enhancing the level of self-regulation in EFL learners. Another possible explanation for this enhancement is that discovery learning approach engages learners more and more in an active learning process so that storage and retrieval of the information would be better than other educational methods.

Our findings provide more evidence for the other studies conducted by Sadeghi and Khezrlou (2012), Araya, Peña, Rodríguez, Spate, \&Vergara (2013), Mizumoto (2013), and Ebrahimi, Azhideh, \&Aslanabadi (2015). Sadeghi and Khezrlou's (2012) study in the field of computer-based learning compared the students' utilization of self-regulated vocabulary strategies in texts with the help of their first and second language hints written in marginal glosses and their use of computer-based manners. Their work also studied the impact of strategy use in L2 proficiency level, gender, and age. The results indicated that self-regulation is mostly shown in computer-based learning situations than in paper-based learning approaches. Moreover, they stated that in computer-based learning situation, a higher level of autonomy is engaged and this increases learners' self-regulation.

However, the results do not support those of Kirschner, Sweller, and Clark's (2006) study, in that, they found discovery learning to have a minor impact in teaching and learning and they asserted that it has negative impact on learners' understandings and organization of information. One possible explanation for this contradiction is that, they did not conduct any empirical study to determine discovery learning's effectiveness and relied on their theoretical assertion.

The limitation of the present study was that the number of male and female participants was not equal in all groups and random selection was not possible. We recommend further studies using postmethod maxims to investigate EFL teachers' level of self-regulation. Moreover, similar studies can be implemented on other levels of language proficiency. 


\section{REFERENCES}

[1] Tseng W. T., Dörnyei Z., and Schmitt N., A new approach to assessing strategic learning: The case of self-regulation in vocabulary acquisition, Applied Linguistics. 27 (1), 78 (2006).

[2] Alqahtani M., The importance of vocabulary in language learning and how to be taught, Ijote. III (3), 21 (2015).

[3] Ebrahimi Z., Azhideh P., and Aslanabadi H., The effects of teaching vocabulary learning strategies on Iranian EFL learners 'vocabulary development, Int. J. Studies in English Language and Literature. 3(1), 57 (2015).

[4] Wilkins D., Linguistics in Language Teaching, Arnold, London, 111 (1972).

[5] Mizumoto A., Effects of self-regulated vocabulary learning process on self-efficacy, Innovation in Language Learning and Teaching. 7(3), 253 (2013).

[6] Constantinescu A., Using technology to assist in vocabulary acquisition and reading comprehension, The Internet TESL Journal. 13(2), (2007).

[7] Maftoon P., and Tasnimi M., Using self-regulation to enhance EFL learners' reading comprehension, Journal of Language Teaching and Research. 5(4), 844 (2014).

[8] Balım A. G., The effects of discovery learning on students' success and inquiry learning skills, Egitim Arastirmalari-Eurasian Journal of Educational Research. 35, 1 (2009).

[9] Saif Modhish A., and Talib Al-Kadi A., Internet integration in EFL college instruction: Attitudes and perspectives, Int. J. Studies in English Language and Literature. 4(6), 52 (2016).

[10] Sadeghi K., and Khezrlou S., Self-regulated vocabulary strategy use: Implications for CALL and individual variables, MEXTESOL Journal. 36, 1 (2012).

[11] Araya D., Peña R., Rodríguez N., Spate S., and Vergara K., Learning strategies and selfregulation in vocabulary acquisition: A research project about EFL learners study experience and achievement, Master Thesis University of Chile. Chile (2013).

[12] Kirschner P., Sweller J., and Clark R. E., Why unguided learning does not work: An analysis of the failure of discovery learning, problem-based learning, experiential learning and inquiry-based learning, Educational Psychologist. 41(2), 75 (2006).

\section{AUTHORS' BIOGRAPHY}

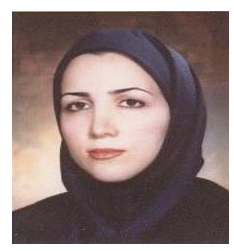

Mahshad Tasnimi, $\mathrm{PhD}$, is an assistant professor of TEFL at the English department of Islamic Azad University, North-Tehran branch, Tehran, Iran. She is interested in second language acquisition, language teaching methodology and testing.

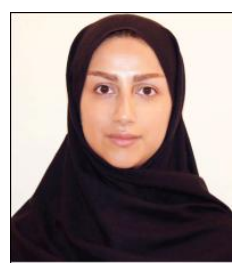

Mahya Afzalinejad Ravari, has awarded her Master's degree in TEFL in Islamic Azad University, North-Tehran branch. Her research direction is psychology of language and postmethod era. 